Reply from the Authors: We thank Dr. Masdeu for his interest and agree that damage to the anterior thalamic structure may have also contributed to the patient's temporal disorientation.

Anterior thalamic nuclei have strong connections to the posterior cingulate cortex and little connection to the anterior cingulate cortex. ${ }^{6}$ The mediodorsal thalamic nucleus connects to both anterior and posterior cingulate cortices. In our case, both the anterior and posterior cingulate cortices were hypometabolic. For this reason, we emphasized the role of the mediodorsal thalamic nucleus.

It is difficult to determine the subregion within the thalamus that is the culprit for our patient's disability. As Dr. Masdeu suggested, the mammillothalamic tract pathway may also participate in the processing of time information.

Jae-Kyu Roh, Soon-Tae Lee, Kyoung-Min Lee, Seoul, South Korea
Disclosure: See original article for full disclosure list.

Copyright (C) 2011 by AAN Enterprises, Inc.

1. Lee ST, Chu K, Kim M, Roh JK. Isolated and prolonged loss of time orientation. Neurology 2010;75:1120.

2. Kumral E, Gulluoglu H, Dramali B. Thalamic chronotaraxis: isolated time disorientation. J Neurol Neurosurg Psychiatry 2007;78:880-882.

3. Aggleton JP, O'Mara SM, Vann SD, Wright NF, Tsanov M, Erichsen JT. Hippocampal-anterior thalamic pathways for memory: uncovering a network of direct and indirect actions. Eur J Neurosci 2010;31: 2292-2307.

4. Markowitsch HJ. Diencephalic amnesia: a reorientation towards tracts? Brain Res 1988;472:351-370.

5. Ghika-Schmid F, Bogousslavsky J. The acute behavioral syndrome of anterior thalamic infarction: a prospective study of 12 cases. Ann Neurol 2000;48:220-227.

6. Vogt BA, Rosene DL, Pandya DN. Thalamic and cortical afferents differentiate anterior from posterior cingulate cortex in the monkey. Science 1979;204:205207.

\title{
CORRECTION
}

\section{The rising prevalence and changing age distribution of multiple sclerosis in Manitoba}

In the article "The rising prevalence and changing age distribution of multiple sclerosis in Manitoba" by R.A. Marrie et al. (Neurology ${ }^{\circledR}$ 2010;74:465-471), a programming error at Manitoba Health and Healthy Living inadvertently excluded some individuals with diagnostic codes for multiple sclerosis, resulting in an incomplete dataset. The administrative case definition for multiple sclerosis and main conclusions of the paper regarding incidence and prevalence are unchanged, but the incidence and prevalence figures originally reported in the text, tables, and figures are underestimated. The updated article and supplemental material are available as data supplements to this erratum at http://www.neurology.org/content/ $77 / 11 / 1105 /$ suppl/DC1. The authors regret the error.

Supplemental Data

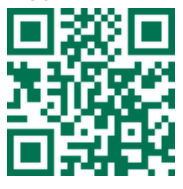




\section{Neurology}

The rising prevalence and changing age distribution of multiple sclerosis in Manitoba Neurology 2011;77;1105

DOI 10.1212/WNL.0b013e31822cd683

This information is current as of September 12, 2011

Updated Information \&

Services

Supplementary Material

Permissions \& Licensing

Reprints including high resolution figures, can be found at: http://n.neurology.org/content/77/11/1105.full

Supplementary material can be found at: http://n.neurology.org/content/supp1/2011/09/11/77.11.1105.DC1

Information about reproducing this article in parts (figures,tables) or in its entirety can be found online at:

http://www.neurology.org/about/about_the_journal\#permissions

Information about ordering reprints can be found online:

http://n.neurology.org/subscribers/advertise

Neurology ${ }^{\circledR}$ is the official journal of the American Academy of Neurology. Published continuously since 1951, it is now a weekly with 48 issues per year. Copyright Copyright () 2011 by AAN Enterprises, Inc.. All rights reserved. Print ISSN: 0028-3878. Online ISSN: 1526-632X.

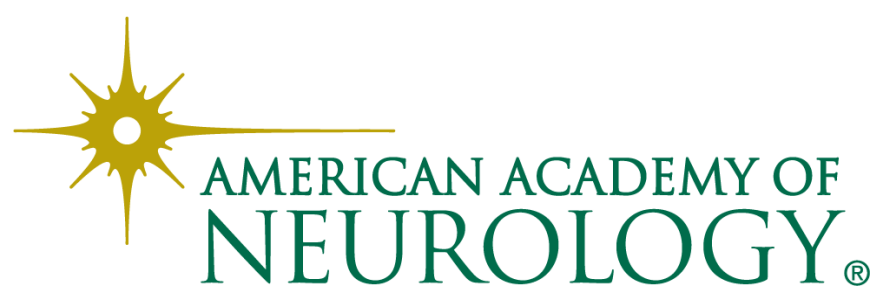

